\title{
The impact of gainsharing in the automotive parts manufacturing industry of South Africa
}

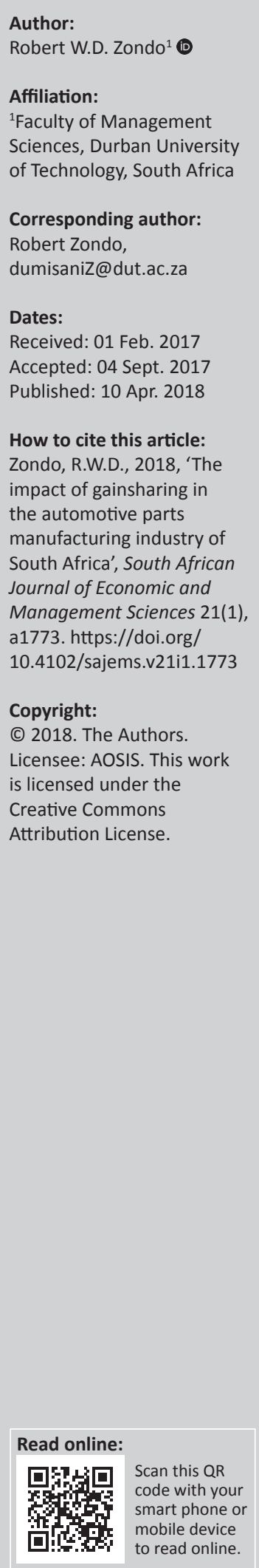

The majority of South Africans expect greater prosperity that can be accomplished through greater employment, high productivity and wage increases. Increased productivity can finance higher wages without burdening the customer with higher selling prices. Consequently, there should be strong co-operation between management and labour to improve productivity, thereby ensuring the survival of South African companies. To achieve this objective, organisations find themselves turning to their employees for creative suggestions and ideas on better ways of doing things. This sentiment underpins the concept of gainsharing. Gainsharing is a formula-based company-wide programme that offers employees a share in the financial gains of a company as a result of its improved performance. This motivation boosts a company's productivity and radically reduces the cost of waste, spoilage, rejects and rework. This study examined the impact of a gainsharing programme on the improvement of labour productivity in the automotive parts manufacturing sector. The study investigated the production and related experience of two automotive parts manufacturing companies (referred to as A and B in this study) that have adopted a gainsharing strategy. The two companies operate in the eThekwini District Municipality in KwaZulu-Natal. It assessed if gainsharing is responsible for company labour productivity improvements. The investigation was achieved by collecting pre- and post-gainsharing quarterly data for spoilage, absenteeism, capital investment and labour productivity. Gainsharing improves labour productivity and reduces spoilage and absenteeism rates. In order to maximise performance, a comprehensive performance policy must be developed, which aligns pay (and other incentives) to performance. The study uncovered the strengths and weaknesses of gainsharing for labour productivity improvement in South Africa.

\section{Introduction}

Productivity has generated tremendous interest among economists. Parry and Lacey (2000) define productivity as management's ability to combine resources optimally and utilise them fully in order to maximise production per unit of resource input. Today, organisations are faced with the challenge of promoting competitiveness and innovative productivity improvement among employees. As a result, Fourie (2008) states that organisational effectiveness depends on an appropriate reward system and that, in order to maximise performance, a comprehensive performance policy must be developed, which aligns pay (or other incentives) to performance. According to Armstrong (2010), gainsharing is an incentive strategy that meets these requirements. Gainsharing is a compensation system that includes employees in plans to improve performance so that they, and management, share any gains (Weiss 2006). It is about improving productivity and attracting and retaining high achievers as well as creating a working environment that encourages worker participation (Rondeau 2007). It also provides the opportunity for linking improved performance to improved compensation and is a means of creating the kind of workplace that attracts motivated risk-takers and work teams. Consequently, gainsharing can be motivated as a tool to increase productivity as out-of-pocket expenses are generally low, because any payouts accrued by workers are linked to future unit performance, and any realised gains are distributed between employees and the company. An effective gainsharing programme involves a diverse set of factors, for instance, profitability, labour costs, material savings and, most importantly, employee participation and involvement (Ritson 2008). Hence, organisations in South Africa (SA) are encouraged to revise their reward philosophies and develop reward strategies, policies and practices that help to achieve new business goals and support organisational and cultural change. Such developments should be based on an understanding of the economic

Note: This article is partially based on the author's thesis of the degree of Doctor of Commerce in the Faculty of Commerce, Law and Public Administration at the University of Zululand, South Africa, with promotor Dr K. Nel and co-promotors Prof. E. Contogiannis and Mr I. Kaseeram, November 2009, available here: http://uzspace.uzulu.ac.za/bitstream/handle/10530/542/research+(productivity+gains haring).pdf.txt?sequence=3 
factors affecting pay, the significance of the psychological contract and the practical implications of motivation theory as these affect the provision of both financial and non-financial rewards (Smith 2007). Interest in performancerelated pay incentives like gainsharing in various sectors of economic activity is increasing. Gainsharing is a desirable alternative as it can contribute to raising the competence levels and productivity improvement of an organisation (Masternak 2009).

\section{Problem statement: Low labour productivity level in South Africa}

South Africa showed a weakening of productivity growth to $-0.4 \%$ in 2014 , while total factor productivity growth declined at an even higher rate of $-3.3 \%$ (Conference Board 2015). South African companies are faced with the challenge of promoting competition and innovation in productivity improvement among employees. Their labour productivity in the manufacturing sector, is low when compared to Korea, the United States of America (USA), Taiwan, Japan, France and the United Kingdom (UK) (Klein 2012). In 2014, they only achieved $36 \%$ of the USA productivity level (Conference Board 2015).

It is against this background that the study focuses on a gainsharing programme, given the low labour productivity levels in the South African manufacturing industries (UNIDO 2013). Gainsharing increases company performance (Hanlon \& Taylor 2005), improves labour productivity and decreases absenteeism (Shonfield 2003). Studies on the use of gainsharing programme in SA are lacking (Grobler et al. 2006). Hence, this study investigates whether gainsharing can increase labour productivity in the selected automotive parts manufacturing companies. It explores the suitability of gainsharing as an appropriate tool for labour productivity improvement.

\section{Literature review}

This section discusses the overview of gainsharing for employee participation. It elaborates on how gainsharing as a programme supports organisational improvement strategy.

\section{Overview of gainsharing for employee participation}

The central theme in gainsharing is employee involvement. It is a systematic tool that is carried out at all stages of implementation, including design and periodic evaluation (Armstrong 2010). For gainsharing to be successful, it must link two of the most important areas in organisational behaviour, namely employee participation and positive employee involvement (Masternak 2009). Hence, this section presents the overview of gainsharing for employee participation.

Under gainsharing schemes, knowledge sharing is formalised through an employee suggestion system. Workers are encouraged to participate in various ways. For instance, they write down cost-saving ideas and submit them to a committee, generally made up of employee and management representatives, who determine the viability of the suggestion (Masternak 2009). These savings become part of a pool of money that is distributed to all participating employees in the form of a gainsharing bonus or reward (Rahman 2011). Although the financial element is a key feature of gainsharing, its strength as a process for improving performance, lies in other important features such as ownership, involvement and communication (Armstrong 2010).

The participation structure of gainsharing varies according to organisations and tends to grow and evolve over time (Masternak 2009). Initially, involvement may be as small as conducting regular communication meetings or as major as forming self-directed work teams (Armstrong \& Stephens 2005). However, Rondeau (2007) notes that team-based suggestion systems are common gainsharing participation structures. Basically, employee involvement teams are formed to solicit and review performance improvement suggestions from other members of the workforce. The groups are fixed and meet on a regular basis to approve and implement ideas within their spending authority. Suggestions that are approved by teams, but are beyond its spending authority, are advanced to a higher level review or steering teams.

Roman (2009) investigated how making changes to a teambased incentive programme affected productivity, product quality and absenteeism in three large manufacturing plants in Texas (in the USA). Results indicated that there were significant improvements in all of these areas. Furthermore, the investigation noted that changes in organisations must be linked to changes in incentive schemes if they are to be continuously successful. Irrespective of the employee involvement system the organisation chooses it is critical that all the problems or challenges are addressed, questions are answered and employee ideas are given proper consideration. Hietpas (2008), in a study of gainsharing in the building industry in the USA, identified employee involvement at all stages of programme implementation as vital. He noted that meetings between mid and upper management and employees must take place frequently so that discussions about important issues are not being ignored. The aforementioned are key issues in separating gainsharing successes from gainsharing failures.

\section{Gainsharing as a programme that supports organisational improvement strategy}

Companies go through stages of growth, maintenance and decline, each of which calls for a different compensation strategy (Armstrong 2010). As a result, successful plans are not introduced as isolated initiatives but in response to what other companies are doing in different stages. They are developed from clear objectives and should form part of a comprehensive management strategy that engages employees in a collective effort to achieve key business goals. Management use such plans in accordance with the 
direction the organisation follows. They develop the right mix and levels of financial and non-financial rewards in order to support their business strategies (Remmen 2003). Bowey (2003) contends that companies without clearly stated objectives generally have unsuccessful compensation plans. Successful companies operate their plans as part of a holistic approach involving senior management support and a wide range of team building, performance management and communication initiatives. Hence, gainsharing should be viewed as a complex organisational development intervention and not simply as an incentive system (Matthew \& Sanjiy 2005). The reasons and conditions under which gainsharing alters employee behaviour, remain to be learned about. According to Wellbourne, Bakin and Gomez-Mejia (1995), most of the existing literature indicates that employee involvement drives gainsharing results. However, the participation models are loosely specified, leading to a belief that employee involvement is a necessary precedent to behaviour. Therefore, the financial reward is but one dimension of a gainsharing programme. The system has a behavioural influence with links to social psychological constructs (Arnolds \& Boshoff 2002). Heath (1999) in Arnolds and Boshoff (2002) indicates that the social psychology suggests that pay will affect behaviour only if employees have an internal desire for rewards and that the intrinsic rewards will influence behaviour only when something in the external environment makes that behaviour worthwhile.

Consequently, gainsharing programmes are not quick fixes to inherent problems but are devices that take advantage of a focused organisational strategy that combines employee participation and an incentive system. Fundamentally, gainsharing rewards motivated employees and saves the company money (Gardner 2011). If high productivity is required over a short period, incentives offered are better than the normal pay. Employees under gainsharing reward structures are expected to engage in more co-operative behaviours, including sharing their ideas for saving costs and improving production, than employees under more competitive, individual-based compensation systems (Tjosvold 2004). Gainsharing offsets one of the downsides of flatter structures, namely fewer promotion opportunities. It raises the level of both intrinsic and extrinsic rewards, particularly for that portion of the workforce that is predisposed to make an extra effort. It helps motivated employees take a keener interest in organisations that do not offer promotion as an incentive (Tsui 2003). Therefore, it enables the organisation to recognise its employees' creativity and intelligence in ways other than increasing their rank or formal status. The organisational perspective of gainsharing is linked to organisational behaviour that plays a pivotal role in understanding employee behaviour (Wellbourne \& Gomez-Mejia 2011). In this regard, employees must perceive that gainsharing is properly set up and that procedures are fair and objective.

In the USA, Brazil and parts of Europe, gainsharing creates a working environment that encourages worker participation and provides opportunity for linking improved performance to better compensation (Wellbourne \& Gomez-Mejia 2011). According to Leitman et al. (2009), in the private health sector in the USA, a pay-for performance programme introduced at a large private hospital between July 2006 and June 2009 resulted in a $\$ 25$ million reduction in costs. The gainsharing programme proved an incentive for medical staff to reduce hospital costs while maintaining quality care. At the Ford Motor Company (in the USA), employees at dealerships are given purchasing incentives (Sachin \& Roble 2008). If they can buy the part below the normal purchase price, they get a share of the overall savings that are made. The aforesaid findings bring important perspectives to the impact of gainsharing in a global context.

\section{Hypothesis}

The study is based on the following assumption:

H1: The implementation of a gainsharing programme leads to labour productivity improvement in the automotive parts manufacturing companies.

\section{Methodology}

The method for this research will be discussed under the following headings, namely companies that participated in the study, data collection, as well as measurement and data analysis.

\section{Companies that participated in the study}

The study is exploratory in nature comparing pre- and postgainsharing intervention using quantitative research tools. A convenience sample utilising two large companies that operate in the automotive parts industry situated within the e-Thekwini District Municipality in the Province of KwaZuluNatal in SA was used. The two companies that adopted gainsharing as an incentive strategy agreed to participate in the study. They are identified as companies A and B. Company A had 1005 employees, while company B had 1302 employees. They both operate a three-shift system. Table 1 presents a percentage breakdown of employees in terms of their level of activities for companies A and B.

\section{Data collection}

The collection of data from the two automotive parts manufacturing companies was carried out in two phases. This involved the collection of pre- and post-gainsharing results for spoilage, absenteeism, capital investment and labour productivity. The pre-gainsharing results were quarterly data reflecting each company's performance over the 3 years prior to the implementation of gainsharing.

TABLE 1: Percentage breakdown of employees in terms of their level of activities.

\begin{tabular}{llcc}
\hline Level of activity & Company A (\%) & Company B (\%) \\
\hline 1. & Plan management & 3.0 & 4.7 \\
2. & Support administration staff & 11.0 & 9.2 \\
3. & Team leaders & 5.2 & 7.1 \\
4. & Line functional employees & 80.8 & 79.0 \\
\hline
\end{tabular}


This includes data from the first quarter of 2005 to the final quarter of 2007. The post-gainsharing data reflect company performances 2 years after gainsharing was implemented. This includes data from the first quarter of 2008 to the final quarter of 2010.

\section{Measurement and data analysis}

The company's quarterly time series data on spoilage, absenteeism, number of workers involved in production, capital investment and labour productivity rates were used. Although company A and B are relatively similar in nature, the data from two companies were collected for an optimum sample size so that statistically valid results could be obtained. The measurements were based on 22 observations per company. Therefore, the results are based on a total of 44 observations.

Additionally, a dummy variable that assumed the value of 0 and 1 to represent the pre- and post-gainsharing periods, respectively, was introduced into the ordinary least squares (OLS) model. The aim was to isolate the pre- and post-labour productivity effects. Consequently, if gainsharing proved to be a useful strategy in raising labour productivity levels, this would result in a statistically significant coefficient on the dummy variable.

Hence, the favourable findings regarding the cointegrating tests enabled the study to engage in quantitative analysis involving OLS in order to quantify the magnitude of the impact that the implementation of gainsharing has had on labour productivity. Cointegration provides evidence of a long-run relationship between variables (Juselius 2006).

The OLS model used was as follows: Labour productivity $=\mathrm{B}_{\mathrm{o}}$ $+\mathrm{B}_{1}$ Spoilage $+\mathrm{B}_{2}$ Absenteeism $+\mathrm{B}_{3}$ Number of workers involved in production $+\mathrm{B}_{4}$ Investment $+\mathrm{B}_{5}$ Pre and Post-dummy

The above model assumes that labour productivity is a function of spoilage rate, absenteeism rate, the number of workers involved in production, investment and gainsharing strategy. The investment variable is the labour productivity lagged by 1 period (i.e. 1 quarter). This variable aims to capture previous machinery input and skills obtained by workers through both skills development programmes and learning through work experience.

For the study to achieve its objective, the stationarity tests (as shown in Table 2) were conducted in order to determine the status of the variables.

The results for both companies' pooled data indicate that the variables exhibit mixed orders of integration. If one ran the OLS models that had non-cointegration level variables, this could have resulted in spurious regressions. As a result, the following tests in Table 3 were carried out on the assumption that the cointegrating vector comprises the labour productivity, spoilage rate, absenteeism, number of workers and the exogenous policy dummy variables.

The above tests show that the variables of company A and B have a cointegrating relationship. As a result, there is more than one cointegrating relationship in the pooled data of company A and B (also shown as AB) in Table 3. This indicates

TABLE 2: Augmented Dickey-Fuller stationarity test results.

\begin{tabular}{|c|c|c|c|c|c|}
\hline Variables & Company & Level & $\begin{array}{c}\text { First } \\
\text { difference }\end{array}$ & $\begin{array}{l}\text { Critical } \\
\text { values }\end{array}$ & Conclusion \\
\hline \multirow[t]{3}{*}{$\begin{array}{l}\text { Labour } \\
\text { productivity }\end{array}$} & $A$ & -0.929 & -3.952 & $-3.831(1 \%)$ & $\begin{array}{l}\text { Stationary after } \\
\text { 1st differencing }\end{array}$ \\
\hline & B & 0.603 & -4.258 & $-3.809(1 \%)$ & $\begin{array}{l}\text { Stationary after } \\
\text { 1st differencing }\end{array}$ \\
\hline & $A B$ & -1.559 & -5.780 & $-3.597(1 \%)$ & $\begin{array}{l}\text { Stationary after } \\
\text { 1st differencing }\end{array}$ \\
\hline \multirow[t]{3}{*}{ Spoilage rate } & A & -3.628 & -6.685 & $-3.809(1 \%)$ & $\begin{array}{l}\text { Stationary after } \\
\text { 1st differencing }\end{array}$ \\
\hline & B & -2.844 & -6.817 & $-3.809(1 \%)$ & $\begin{array}{l}\text { Stationary after } \\
\text { 1st differencing }\end{array}$ \\
\hline & $A B$ & -5.470 & - & $-4.186(1 \%)$ & Stationary in levels \\
\hline \multirow[t]{3}{*}{ Absenteeism } & $A$ & -4.731 & - & $-3.788(1 \%)$ & Stationary in levels \\
\hline & B & -4.853 & - & $-3.809(1 \%)$ & Stationary in levels \\
\hline & $A B$ & -6.573 & - & $-4.186(1 \%)$ & Stationary in levels \\
\hline \multirow{3}{*}{$\begin{array}{l}\text { Number of } \\
\text { employees } \\
\text { involved in } \\
\text { production }\end{array}$} & $A$ & -0.875 & -5.387 & $-3.809(1 \%)$ & $\begin{array}{l}\text { Stationary after } \\
\text { 1st differencing }\end{array}$ \\
\hline & B & -0.982 & -5.194 & $-3.809(1 \%)$ & $\begin{array}{l}\text { Stationary after } \\
1 \text { st differencing }\end{array}$ \\
\hline & $A B$ & -1.663 & -6.325 & $-3.597(1 \%)$ & $\begin{array}{l}\text { Stationary after } \\
\text { 1st differencing }\end{array}$ \\
\hline
\end{tabular}

Note: The data set spanned 2005-2010. The stationarity tests for other variables (except spoilage rate) were conducted on the assumption of intercept and no trend was used. In the spoilage rate, the assumption of trend and intercept was used. All the critical values are based at the $1 \%$ significance level. A battery of other unit root tests (not reported) confirmed the above Augmented Dickey-Fuller (ADF) test results.

TABLE 3: Johansen trace and maximum eigenvalue statistics for cointegrating vector

\begin{tabular}{|c|c|c|c|c|c|c|}
\hline \multirow[t]{2}{*}{ Company } & \multicolumn{3}{|c|}{ Trace test } & \multicolumn{3}{|c|}{ Maximum eigenvalue test } \\
\hline & $\begin{array}{l}\text { No. of hypothesised } \\
\text { cointegrating equations }\end{array}$ & Trace statistic & $5 \%$ critical value & $\begin{array}{l}\text { No. of hypothesised } \\
\text { cointegrating equations }\end{array}$ & Maxi-eigen statistic & $5 \%$ critical value \\
\hline A & $\mathrm{H}_{0}: r=0, \mathrm{H}_{1}: r \geq 1$ & $63.78^{* *}$ & 47.86 & $\mathrm{H}_{0}: r=0, \mathrm{H}_{1}: r=1$ & $34.78^{* *}$ & 27.58 \\
\hline \multirow[t]{2}{*}{ B } & $\mathrm{H}_{0}: r=0, \mathrm{H}_{1}: r \geq 1$ & $53.28 * *$ & 47.86 & $\mathrm{H}_{0}: r=0, \mathrm{H}_{1}: r=1$ & $30.57 * *$ & 27.58 \\
\hline & $\mathrm{H}_{0}: r \leq 1, \mathrm{H}_{1}: r \geq 2$ & 22.70 & 29.80 & $\mathrm{H}_{0}: \mathrm{r} \leq 1, \mathrm{H}_{1}: r=2$ & 14.47 & 21.13 \\
\hline \multirow[t]{3}{*}{$A B$} & $\mathrm{H}_{0}: r=0, \mathrm{H}_{1}: r \geq 1$ & $84.96 * * *$ & 47.86 & $\mathrm{H}_{0}: r=0, \mathrm{H}_{1}: r=1$ & $40.76 * * *$ & 27.58 \\
\hline & $\mathrm{H}_{0}: r \leq 2, \mathrm{H}_{1}: r \geq 3$ & $16.98^{* *}$ & 15.50 & $\mathrm{H}_{0}: r \leq 2, \mathrm{H}_{1}: r=3$ & $16.57^{* *}$ & 14.26 \\
\hline & $\mathrm{H}_{0}: r \leq 3, \mathrm{H}_{1}: r \geq 4$ & 0.412 & 3.841 & $\mathrm{H}_{0}: r \leq 3, \mathrm{H}_{1}: r=4$ & 0.412 & 3.841 \\
\hline
\end{tabular}

*** and $* *$ denote that the statistics under consideration are significant at the $1 \%$ and $5 \%$ significance levels, respectively.

Note: An unrestricted vector autoregression (VAR) of lag order two (i.e. $p=2$ ) was used; hence, the differenced vector error correction model had a lag order of 1 . The selection of the lag order was based on discretion because of small data size. Companies AB represent pooled data of companies A and B. The companies' A and B models were based on the assumption that the level of data and cointegrating equations have linear trends. Models of company AB were based on the assumption that the level data have cointegrating equations and linear trends. 
that the results of Tables 5-7 consist of statistically valid data that could perhaps represent long-run relationships.

\section{Study results}

\section{Pre- and post-gainsharing comparison}

Table 4 presents the average indexes for spoilage, absenteeism and labour productivity. It shows the extent of percentage change from pre- to post-gainsharing periods.

Table 4 shows a slight decrease of $0.32 \%$ on spoilage rates when the post-gainsharing results are compared with pregainsharing results. It also shows a marginal increase on absenteeism rates of $0.12 \%$. However, labour productivity rates have a substantial increase of $3.76 \%$.

\section{Labour productivity results}

Table 5 presents the results for labour productivity as a dependent variable to absenteeism and spoilage rates, the number of workers involved in production, as well as gainsharing.

Results in Table 5 indicate that absenteeism and spoilage rates, as well as the number of workers involved in production at $t$-values $0.99,-0.24$ and 1.63 , respectively, have no relationship to labour productivity. Their results are below the critical $t$-value of 2.02 at the $5 \%$ level of significance, thus accepting the null hypothesis of relationship between these variables. This indicates that absenteeism and spoilage rates as well as the number of workers involved in production are independent of labour productivity. However, results also show that the gainsharing programme has a positive relationship and is statistically significant to labour productivity.

TABLE 4: Pre- and post-gainsharing comparison

\begin{tabular}{llccc}
\hline No. & Variable & $\begin{array}{c}\text { Pre-gainsharing } \\
\text { period (\%) }\end{array}$ & $\begin{array}{c}\text { Post-gainsharing } \\
\text { period (\%) }\end{array}$ & $\begin{array}{c}\text { Percentage difference } \\
\text { (post less pre- } \\
\text { gainsharing results) } \\
(\%)\end{array}$ \\
\hline 1. & Spoilage & 6.71 & 6.39 & -0.32 \\
2. & Absenteeism & 5.37 & 5.49 & +0.12 \\
3. & $\begin{array}{l}\text { Labour } \\
\text { productivity }\end{array}$ & 4.43 & 8.19 & +3.76 \\
\hline
\end{tabular}

TABLE 5: Labour productivity results.

\begin{tabular}{|c|c|c|c|}
\hline Regression & Coefficient & $t$-statistic & Probability \\
\hline Constant ( $\mathrm{B}_{\mathrm{o}}$ ) & -1.411336 & -0.529345 & 0.5998 \\
\hline $\begin{array}{l}\text { Past capital } \\
\text { investment }\end{array}$ & 0.339051 & 3.278933 & 0.0023 \\
\hline Absenteeism & 0.037038 & 0.994769 & 0.3265 \\
\hline Spoilage rate & -0.012894 & -0.239115 & 0.8124 \\
\hline Number of workers & 0.609476 & 1.625787 & 0.1127 \\
\hline Gainsharing dummy & 0.212432 & 3.382496 & 0.0017 \\
\hline$R$-squared & 0.848275 & $F$-statistics & 33.54530 \\
\hline Adjusted $R^{2}$ & 0.822988 & Prob (F-statistic) & 0.000000 \\
\hline $\begin{array}{l}\text { Standard error of } \\
\text { regression }\end{array}$ & 0.093561 & Mean dependent var. & 4.560438 \\
\hline $\begin{array}{l}\text { Standard deviation } \\
\text { dependent variable }\end{array}$ & 0.222379 & Durbin-Watson stat. & 1.579431 \\
\hline
\end{tabular}

Note: Regression data: 2005-2010 for 43 observations after adjustments. The following OLS estimation is based on the equation: Labour productivity $=B_{0}+B_{1}$ Past capital investment $B_{2}$ Absenteeism $+B_{3}$ Spoilage $+B_{4}$ Workers $+B_{5}$ Post-gainsharing dummy.
This is determined by its $t$-value of 3.38 and is above the critical $t$-value of 2.02 at the $5 \%$ level of significance, thus accepting the assumption (i.e. the alternative hypothesis) of a significant relationship between the two variables. This indicates that the gainsharing programme is dependent on labour productivity. Positive relationship entails that the implementation of the gainsharing programme increased labour productivity.

\section{Labour productivity results with capital investment lagged by 1 quarter}

Results in Table 6 illustrate labour productivity as a dependent variable to past capital investment (lagged by 1 quarter), absenteeism and spoilage rates, the number of workers involved in production, as well as gainsharing.

Table 6 indicates that absenteeism and spoilage rates as well as the number of workers involved in production (1 quarter after the two companies have invested to capital) at 0.99 , -0.24 and 1.63 , respectively, have no relationship to labour productivity. Their results are below the critical $t$-value of 2.02 at the $5 \%$ level of significance, thus accepting the null hypothesis of relationship between labour productivity and these (independent) variables. This indicates that absenteeism and spoilage rates as well as the number of workers involved in production are independent of labour productivity. However, results show that past capital investments (lagged by 1 quarter) and a gainsharing programme have a positive relationship and are statistically significant to labour productivity. This is determined by their $t$-values of 3.28 and 3.38 for past capital investment and a gainsharing programme, respectively. Their results are above the critical $t$-value of 2.02 at the $5 \%$ level of significance, thus accepting the assumption of a significant relationship between labour productivity and these two (independent) variables. This indicates that past capital investments lagged by 1 quarter and a gainsharing programme are dependent on labour productivity. Positive relationship entails that the implementation of a gainsharing programme as well as past capital investment lagged by 1 quarter increased labour productivity.

TABLE 6: Labour productivity results with capital investment lagged by 1 quarter.

\begin{tabular}{lccc}
\hline Regression & Coefficient & $\boldsymbol{t}$-statistic & Probability \\
\hline Constant (Bo $)$ & -1.411336 & -0.529345 & 0.5998 \\
$\begin{array}{l}\text { Past capital investment } \\
\text { (lagged by 1 quarter) }\end{array}$ & 0.339051 & 3.278933 & 0.0023 \\
Absenteeism & 0.037038 & 0.994769 & 0.3265 \\
Spoilage rate & -0.012894 & -0.239115 & 0.8124 \\
Number of workers & 0.609476 & 1.625787 & 0.1127 \\
Gainsharing dummy & 0.212432 & 3.382496 & 0.0017 \\
$\begin{array}{l}\text { Separate company } \\
\text { A and B data }\end{array}$ & 0.086863 & 0.932715 & 0.3572 \\
$R$-squared & 0.848275 & F-statistics & 33.54530 \\
Adjusted $R^{2}$ & 0.822988 & Prob (F-statistic) & 0.000000 \\
Standard error of regression & 0.093561 & Mean dependent var. & 4.560438 \\
$\begin{array}{l}\text { Standard deviation } \\
\text { dependent variable }\end{array}$ & 0.222379 & Durbin-Watson stat. & 1.579431 \\
\hline
\end{tabular}

Note: Regression data: 2005-2010 for 43 observations after adjustments. The following OLS estimation is based on the equation: Labour productivity $=B_{0}+B_{1}$ Past capital investment (lagged by 1 quarter) $+B_{2}$ Absenteeism $+B_{3}$ Spoilage $+B_{4}$ Workers $+B_{5}$ Post-gainsharing dummy. 


\section{Labour productivity results with capital investment lagged by 2 quarters}

Table 7 illustrates that results for labour productivity as a dependent variable of past capital investment lagged by 2 quarters, absenteeism and spoilage rates, the number of workers involved in production, as well as gainsharing.

Results in Table 7 indicate that absenteeism and spoilage rates, the number of workers involved in production, as well as past capital investments (lagged by 2 quarters) at 1.44 , $-0.66,1.90$ and -0.82 , respectively, have no relationship with labour productivity. Their results are below the critical $t$-value of 2.02 at the $5 \%$ level of significance, thus accepting the null hypothesis of relationship between labour productivity and these (independent) variables. This indicates that past capital investments lagged by 2 quarters, absenteeism and spoilage rates as well as the number of workers involved in production are independent of labour productivity. However, results show that the gainsharing programme has a positive relationship and is statistically significant to labour productivity. This is determined by its $t$-value of 3.19. The result is above the critical $t$-value of 2.02 at the $5 \%$ level of significance, thus accepting the assumption of a significant relationship between labour productivity and gainsharing variable.

\section{Summary of results: Box plots for determining whether the normality and homogeneity of variance have been met}

This section analyses data using factorial designs. It incorporates the box plots to determine whether the factorial ANOVA assumptions of normality and homogeneity of variance have been met. Porkess (2005) explains that the populations represented should be normally distributed (i.e. the normality) making the mean an appropriate measure of central tendency. However, the homogeneity of variance indicates that the population from which the data are sampled should have the same variance. In this study, 'policy

\begin{tabular}{|c|c|c|c|}
\hline$\overline{\text { Regression }}$ & Coefficient & $t$-statistic & Probability \\
\hline Constant $\left(\mathrm{B}_{\mathrm{o}}\right)$ & -2.254516 & -0.812598 & 0.4221 \\
\hline $\begin{array}{l}\text { Past capital investment } \\
\text { (lagged by } 1 \text { quarter) }\end{array}$ & 0.404340 & 2.453661 & 0.0194 \\
\hline $\begin{array}{l}\text { Past capital investment } \\
\text { (lagged by } 2 \text { quarters) }\end{array}$ & -0.109994 & -0.815261 & 0.4206 \\
\hline Absenteeism & 0.061675 & 1.435440 & 0.1603 \\
\hline Spoilage rate & -0.037661 & -0.661727 & 0.5126 \\
\hline Number of workers & 0.753819 & 1.903928 & 0.0654 \\
\hline Gainsharing dummy & 0.202354 & 3.194382 & 0.0030 \\
\hline $\begin{array}{l}\text { Separate company } \\
A \text { and } B \text { data }\end{array}$ & 0.119376 & 1.218377 & 0.2315 \\
\hline$R$-squared & 0.857234 & F-statistics & 29.16462 \\
\hline Adjusted $R^{2}$ & 0.827841 & Prob (F-statistic) & 0.000000 \\
\hline Standard error of regression & 0.093382 & Mean dependent var. & 4.560821 \\
\hline $\begin{array}{l}\text { Standard deviation } \\
\text { dependent variable }\end{array}$ & 0.225060 & Durbin-Watson stat. & 1.686645 \\
\hline
\end{tabular}

Note: Regression data: 2005-2010 for 43 observations after adjustments. The following OLS estimation is based on the equation: Labour productivity $=B+B_{1}$ Past capital investment (lagged by 1 quarter) $+B_{2}$ Past capital investment (lagged by 2 quarters) + $B_{3}$ Absenteeism $+B_{4}$ Spoilage $+B_{5}$ the number of workers involved in production $+B_{6}$ Post gainsharing dummy. $1^{\prime}$ is pre-dummy (i.e. the period before gainsharing was implemented), while 'policy 2 ' is post-dummy (i.e. the period after the gainsharing was implemented). The following Figure 1 presents the box plots for this study.

Figure 1 shows that the mode of change between company A (labelled as 'company 1') and company B (as 'company 2') from pre- (i.e. policy 1) to post- (in policy 2) gainsharing period is homogeneous. Box plots indicate a similar spread of gainsharing results from both companies. Statistical tests suggest that the conditions for homogeneity of variance between the pre- and post-gainsharing periods from the two companies have been met. This is confirmed by Levene's test of equality shown in Table 8.

Porkess (2005) defines Levene's test of equality as an inferential statistic used to assess the equality of variance on different samples. In Levene's test of equality, the statistical procedure assumes that variances of the populations from which different samples are drawn are equal. As a result, the findings in Table 8 show that the obtained similarities between the variances in the samples for companies A and $\mathrm{B}$ at $p$-value 0.008 have occurred. They are below the statistical standard value of 0.05 .

In addition, the interacting factors between the marginal means of pre- and post-gainsharing implementation periods yielded similar patterns between the D means. Hence, there are mean changes between company $\mathrm{A}$ and company $\mathrm{B}$ in relation to pre- and post-policy periods (as shown in Figure 2).

Figure 2 indicates that the implementation of gainsharing improved labour productivity. The findings are confirmed by the results in Sections 'Pre- and post-gainsharing

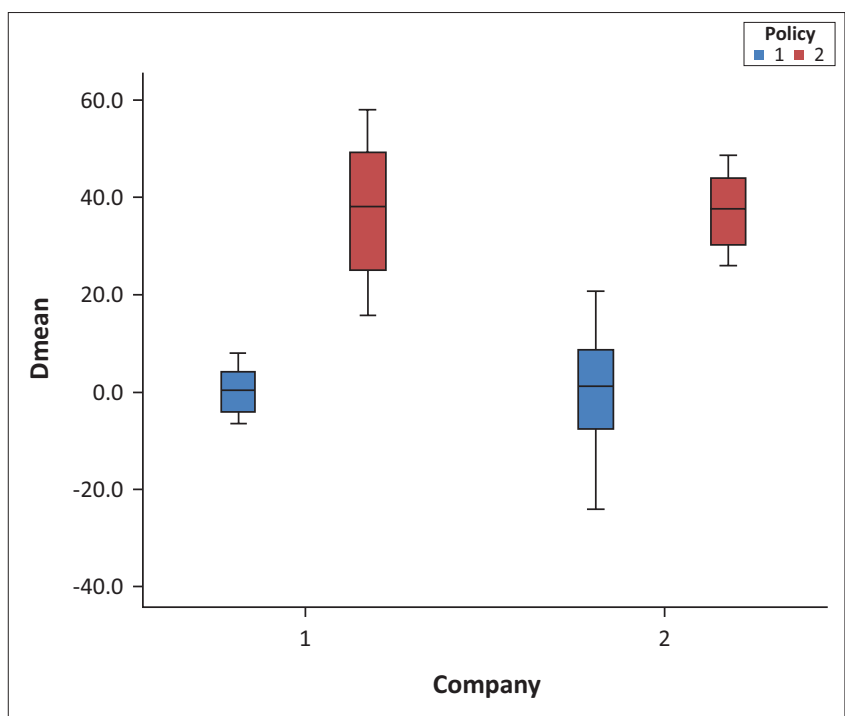

FIGURE 1: Box plots determining the normality and homogeneity of variance.

TABLE 8: Levene's test of equality of error variances

\begin{tabular}{lccc}
\hline $\boldsymbol{F}$ & $d f \mathbf{1}$ & $\boldsymbol{d f} \mathbf{2}$ & Sig. \\
\hline 4.571 & 3 & 38 & 0.008 \\
\hline
\end{tabular}

$F$, Fisher-Snedecor; $d f$, degrees of freedom; Sig., significant. 


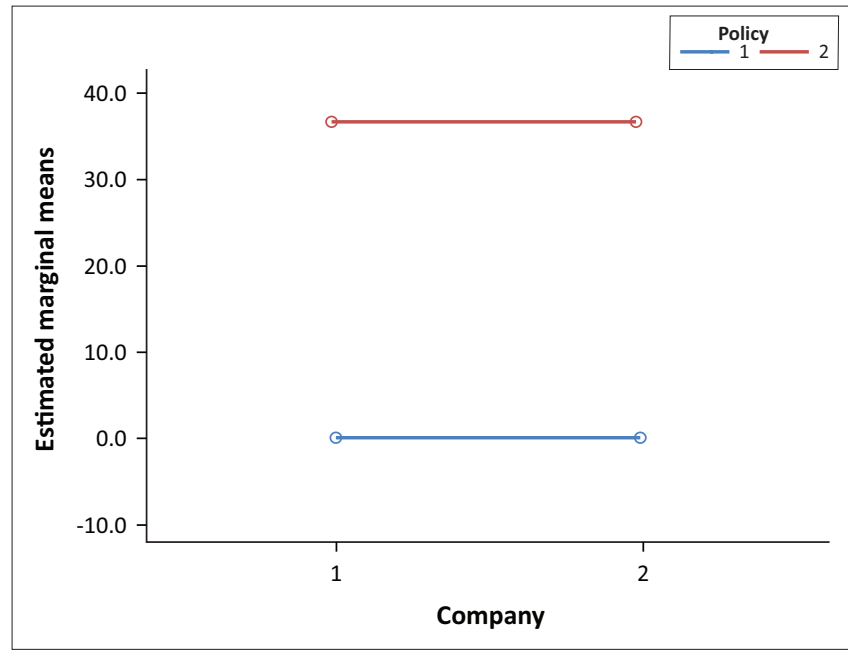

FIGURE 2: Estimated marginal means of $D$ means for companies $A$ and $B$ (as labelled by 1 and 2, respectively).

comparison', 'Labour productivity results' and 'Labour productivity results with capital investment lagged by 1 quarter', which show that gainsharing has a positive relationship with labour productivity.

\section{Discussion}

Results from this study indicate that absenteeism and spoilage rates as well as the number of workers involved in production have no relation to labour productivity. However, it reveals the relationship between a gainsharing programme and labour productivity. The positive relationship indicates that the implementation of a gainsharing programme increases labour productivity. This is supported by Fourie (2008) who states that the organisational effectiveness depends on appropriate reward systems. In addition, Rondeau (2007) indicates that gainsharing is about improving productivity and attracting and retaining high achievers as well as creating a working environment that encourages worker participation. The researcher also measured the impact of a gainsharing programme on labour productivity (one or two quarters after the companies have invested in capital). Similarly, the results show the positive relationship between a gainsharing programme and labour productivity. The relationship indicates that the implementation of a gainsharing programme (one or two quarters after the company has invested in capital) increases labour productivity.

\section{Implications of results for policy and practice}

Organisations in SA are encouraged to revise their reward philosophies and develop reward strategies, policies and practices that help to achieve new business goals and support organisational and cultural change. This must be based on an understanding of the economic factors affecting pay, the significance of the psychological contract and the practical implications of motivation theory as these affect the provision of both financial and non-financial rewards. However, the research has established gainsharing as a programme that facilitates employee satisfaction. Besides the achievement of study objectives, the following conclusions can be made:

- Gainsharing is a desirable alternative as it contributes to raising the competence levels and productivity improvement of an organisation.

- During the gainsharing implementation, the employee involvement teams should be able to solicit and review performance improvement suggestions from other members of the workforce.

- In order to maximise performance, a comprehensive performance policy must be developed, which aligns pay (and other incentives) to performance.

\section{Study limitations}

The study was limited to the automotive parts manufacturing industry within the eThekwini District Municipality. The investigation was conducted with two companies that have adopted gainsharing. As there are 378 registered automotive parts manufacturers in SA (SAinfo 2008) and the investigation was conducted on two of these companies (representing $0.53 \%$ ), the results cannot be generalised to other companies within the sector. Lastly, the econometrics model used was of the OLS variety, solely because of data constraints. Future studies ought to use the more advanced Johansen VAR methodology or panel data analysis, both of which rely on large data sets.

\section{Conclusion}

Gainsharing creates a working environment that encourages worker participation and provides opportunity for linking improved performance to better compensation. However, it is not a quick fix to inherent problems. It is a programme that takes advantage of a focused organisational strategy to combine employee participation and an incentive system.

\section{Future research required}

During the course of this study, issues relating to the longterm survival of gainsharing after implementation were not intensively covered. This includes the applicability of gainsharing to a wider sector of the economic activity including the public sector. The nature of this research did notallow these areas to be covered in depth. It is recommended that future research should examine the following issues in greater depth:

- When to use and when not to use a gainsharing programme

- The applicability of gainsharing for other industrial sectors

- A more comprehensive investigation should be carried out using a randomised sample of the registered automotive component manufacturers that use gainsharing to see if the results can be generalised.

\section{References}

Armstrong, M., 2010, Handbook of reward management practice, Kogan Page, Philadelphia, PA.

Armstrong, M. \& Stephens, T., 2005, A handbook of employee reward management and practice, Kogan Page, New York. 
Arnolds, C.A. \& Boshoff, C., 2002, 'Compensation, esteem valence and job performance: An empirical assessment of Alderfer's ERG theory', International journal of Human Resource Management 13(4), 697-719. https://doi.org/ Journal of Human Resource

Bowey, A.M., 2003, 'Gainsharing: Origins, history, design and results', Academy of Management Journal 19(3), 392-418.

Conference Board, 2015, Productivity brief 2015: Global productivity stuck in the slow lane with no signs of recovery in sight, Business World, New York.

Fourie, D., 2008, 'An examination of an incentive system to maximize performance in an automobile manufacturing environment', unpublished thesis, Rhodes University, Grahamstown.

Gardner, A.C., 2011, 'Goal setting and gainsharing: The evidence on effectiveness', Compensation and Benefits Review 43(4), 236-244. https://doi.org/10.1177/ 0886368711410181

Grobler, P., Wärnich, S., Carrel, M.R., Elbert, N.F. \& Hatfield, R.D., 2006, Human resource management in South Africa, Thomson Learning, London.

Hanlon, S.C. \& Taylor, R.R., 2005, 'An examination of changes in work group communication behaviours following installation of a gainsharing plan', Group and Organisation Studies 16, 52-75.

Heath, C., 1999, 'On the social psychology of agency relationships: Lay theories of motivation overemphasize extrinsic incentives' Organizational Behaviour and Human Decision Processes 78(1), 25-65. https://doi.org/10.1006/obhd.1999.2826

Hietpas, P.C., 2008, 'The financial analysis of the implementation of a gainsharing plan in a construction firm', unpublished thesis, The Graduate School of Wisconsin Menomonie.

Juselius, K., 2006, The Cointegrated VAR model: Methodology and application, advanced texts in econometrics, Oxford University Press, Oxford.

Klein, N., 2012, Real wage, labour productivity, and employment trends in South Africa: A closer look, IMF WP/12/92, IMF Publishing, Washington, DC.

Leitman, M., Levin, R., Lipp, M., Sivaprasad, M.D., Karalakulasingham, M.D., Bernard, D.S. et al., 2010, 'Quality and financial outcomes for inpatient admission: A threeyear experience', Journal of Hospital Medicine 5(9), 501-517. https://doi.org/ year experience',

Masternak, R., 2009, 'Gainsharing: An incentive plan or employee involvement', viewed 17 October 2016, from http://ezinearticles.com/?Article-5---GainsharingOver-the-Long-Term

Matthew, H.R. \& Sanjiv, S.D., 2005, 'Using employee gainsharing plans to improve organizational effectiveness', Benchmarking: An International Journal 12(3), 250-259. https://doi.org/10.1108/14635770510600366

Parry, T. \& Lacey, P., 2000, 'Promoting productivity and workforce effectiveness', Financial Executive 16(6), 51-53.
Porkess, R., 2005, Collins internet-linked dictionary of statistics, HarperCollins, Glasgow.

Rahman, M.S., 2011, 'Assessing the relationship between diversified workforce and reward on employees' performance in the organisation: An exploratory study of private organisations in Bangladesh', International Journal of Employment Studies 19(2), 84-112.

Remmen, D., 2003, 'Performance pays off', Strategic Finance 84(9), 24-31.

Ritson, N., 2008, Strategic management, Neil Ritson and Ventus Publishing, London.

Roman, P.F., 2009, 'An analysis of changes to a team-based incentive plan and its effects on productivity, product quality, and absenteeism', Accounting, Organizations and Society 34(1), 589-618. https://doi.org/10.1016/j.aos.2008.08.004

Rondeau, K.V., 2007, 'The adoption of high involvement work practices in Canadian nursing homes', Leadership in Health Services 20(1), 16-26. https://doi. org/10.1108/17511870710721453

Sachin, J.H. \& Roble, D., 2008, 'Gainsharing in industrial settings', viewed 16 October 2016, from http://www.allbusiness.com/health-care-overview

SAinfo, 2008, South Africa's automotive industry, viewed 14 October 2016, from www.southafrica.info/doing_business/economy/key_sectors/motorindustry boost.html

Shonfield, D., 2003, Spoilt for choice, People Management 9(2), 7-13.

Smith, I., 2007, 'Reward management and HRM', in P. Blyton \& E. Turnbull (eds.), Re-assessing human resource management, pp. 537-538, Sage, London.

Tjosvold, D., 2004, 'Dynamics within participation: An experiment investigation', Group and Organisational Studies 10(3), 260-277. https://doi.org/10.1177/ 105960118501000304

Tsui, A., 2003, 'A multiple-constituency model of effectiveness: An empirical examination at a human resource subunit level', Administrative Science Quarterly 53, 35-63.

UNIDO, 2013, Sustaining employment growth: The role of manufacturing and structural change overview, Industrial Development Report 2013, United Nations, Vienna.

Weiss, M.F., 2006, 'Gain your fair share: Gainsharing makes a comeback', Seminars in Anesthesia, Perioperative Management and Pain 25, 183-186. https://doi.org/ 10.1053/j.sane.2006.05.005

Wellbourne, T.M., Balkin, D.B. \& Gomez-Mejia, L.R., 1995, 'Gainsharing and mutual monitoring: A combined agency-organizational justice interpretation', Academy of Management Journal 38(3), 881. https://doi.org/10.2307/256750

Wellbourne, T.M. \& Gomez-Mejia, L.R., 2011, 'Gainsharing: A critical review and a future research agenda', Journal of Management (online special edition), viewed 20 October 2016, from http://www.humanresourcesiq.com/benefits-compensation/ articles/gainsharing 